\title{
The Decrease in Summer Surface Water Temperature with Altitude in Swiss Alpine Lakes: A Comparison with Air Temperature Lapse Rates
}

\author{
David M. Livingstone,* \\ André F. Lotter, ${ }^{*} \dagger$ and \\ Ian R. Walker $\ddagger$ \\ *Department of Environmental \\ Physics, Swiss Federal Institute of \\ Environmental Science and \\ Technology (EAWAG), \\ Überlandstrasse $133, \mathrm{CH}-8600$ \\ Dübendorf, Switzerland. \\ living@eawag.ch \\ †Geobotanical Institute, University of \\ Berne, Altenbergrain 21, $\mathrm{CH}-3013$ \\ Berne, Switzerland. \\ lotter@sgi.unibe.ch \\ $\ddagger$ Okanagan Institute for Freshwater \\ Studies and Department of Biology, \\ North Kelowna Campus, Okanagan \\ University College, 3333 College \\ Way, Kelowna, British Columbia, \\ Canada V1V 1 V7. \\ iwalker@okanagan.bc.ca
}

\begin{abstract}
Using miniature thermistors with integrated data loggers, the decrease in summer lake surface water temperature (LSWT) with increasing altitude a.s.l. was investigated in 10 Swiss Alpine lakes located between $613 \mathrm{~m}$ a.s.l. and $2339 \mathrm{~m}$ a.s.l. The LSWTs exhibit essentially the same short-term structure as regional air temperature, but are about 3 to $5^{\circ} \mathrm{C}$ higher than the air temperature at the altitude of the lake. LSWTs decrease approximately linearly with increasing altitude at a rate slightly greater than the surface air temperature lapse rate. Diel variations in LSWT are large, implying that single water temperature measurements are unlikely to be representative of the mean. Local factors will affect LSWT more than they affect air temperature, possibly resulting in severe distortion of the empirical relationship between the two. Several implications for paleoclimate reconstruction studies result. (1) Paleolimnologically reconstructed LSWTs are likely to be higher than the air temperatures prevailing at the altitude of the lake. (2) Lakes used for paleoclimate reconstruction should be selected to minimize local effects on LSWT. (3) The calibration of organism-specific quantitative paleotemperature inference models should not be based on single water temperature measurements. (4) Consideration should be given to calibrating such models directly against air temperature rather than water temperature. (5) The primary climate effect on the aquatic biota of high-altitude lakes may be mediated by the timing of the ice cover.
\end{abstract}

\section{Introduction}

General circulation models (GCMs) developed to simulate probable future climate scenarios have consistently indicated that increased greenhouse gas emissions are likely to have their greatest impact at high northern latitudes (Kattenberg et al., 1996). Some studies also suggest that the effect of climate change at high altitudes is likely to be above average (e.g., Beniston et al., 1997). This consideration has focused scientists' attention on acquiring a better understanding of the past, present and future dynamics of climate variables at both high latitudes and high altitudes. The empirical reconstruction of paleoclimates, and especially of paleotemperature, is an essential component of this research (Smol et al., 1991). Paleoclimate reconstruction is not only of intrinsic value; it also allows the validity and predictive power of GCMs to be tested by hindcasting. A vital component of this research is the development of transfer functions that allow paleotemperatures to be inferred from the distributions of subfossil aquatic organisms in lake sediments (e.g., Walker et al., 1991, 1997; Lotter et al., 1997; Olander et al., 1997). These transfer functions are based on the modern distributions of aquatic organisms along the climate gradients represented by transects of either latitude or altitude.

Such transfer functions are traditionally calibrated in terms of lake water temperatures, and therefore generally provide estimates of past water temperatures rather than past air temperatures (e.g., Walker et al., 1991, 1997; Pienitz et a1., 1995; Wunsam et al., 1995; Olander et al., 1997; Weckström et al., 1997).
Use of the inferred water temperatures as a proxy for air temperature depends on the assumption that water and air temperatures are directly linked by a fairly simple monotonic relationship. However, in a study based on 17 lakes situated on the Swiss Plateau, Livingstone and Lotter (1998) showed that lake water temperatures cannot be viewed as mirroring air temperature directly, although correlations between the two can be high, depending on the time of year, the time-scale of the correlation, and the depth in the water column. One rather telling example illustrating the complexity of the relationship between air and water temperatures is the fact that in July and August, air temperatures are positively correlated with the water temperatures in Lake Zurich from the surface down to about $7 \mathrm{~m}$, uncorrelated with the water temperatures between about $7 \mathrm{~m}$ and $12 \mathrm{~m}$, and negatively correlated with the water temperatures between about $12 \mathrm{~m}$ and $20 \mathrm{~m}$ (Livingstone and Lotter, 1998). This latter negative correlation is presumably due to a tendency for the downward convective mixing of heat to occur at low air temperatures but to be suppressed by stable water column stratification at high air temperatures.

In addition to the physical factors that tend to render the relationship between air and water temperatures less simple than one might expect, biological factors add another degree of complexity to the problem. The thermal optima of aquatic biota have often been specified on the basis of a single temperature variable (e.g., a summer lake surface water temperature). This is an oversimplification, since water temperature varies considerably with time of day, time of year, and depth in the water column. Also, depending on the organism in- 
volved, different parts of the life cycle may be spent in different parts of the water column - or indeed in the air, as is the case for all aquatic insects-at different times of the year. In view of these complicating factors, the authors of the present study feel that it is important to develop a clearer understanding of the relationship between air temperature (the variable of interest to climatologists) and lake water temperatures (which most likely regulate the distributions of aquatic biota along a climate gradient). In this initial attempt to investigate the tacit assumption of a direct monotonic relationship between air temperature and lake surface water temperature (hereafter LSWT), the required temperature gradient was provided by selecting lakes situated in the same geographical area, but at a range of different altitudes above sea level.

In mountain areas, surface air temperatures in summer generally decrease approximately linearly with altitude (Tabony, 1985; Barry, 1992). This decrease is principally a result of the decrease in air temperature that occurs in the free atmosphere as a result of the adiabatic vertical mixing of moist air masses, modified by various local and regional surface effects (Tabony, 1985; Barry, 1992). Despite these surface modifications, surface air temperature lapse rates still tend to be similar to the saturated adiabatic lapse rate, a typical value of which is about $6^{\circ} \mathrm{C} \mathrm{km}^{-1}$ (Tabony, 1985). Not only does surface air temperature decrease with increasing altitude; LSWTs do so also, a fact which has already been made use of in paleolimnological calibration studies (e.g., Vyvermann and Sabbe, 1995). The reason for the altitudinal decrease in LSWT is connected with an altitudinal decrease in the so-called lake surface equilibrium temperature (hereafter LSET), i.e., in the temperature at which the net heat flux across the air-water interface is zero (Edinger et al., 1968; Dingman, 1972). The LSET represents a theoretical value to which the LSWT tends. It is partially dependent on surface air temperature, but also on cloud cover (which governs the solar and atmospheric radiation balance), relative humidity (via latent heat exchange) and wind speed (which affects both latent and convective heat exchange). It seems to be affected more by fluctuations in cloud cover and relative humidity than by fluctuations in air temperature (Marti and Imboden, 1986; Livingstone and Imboden, 1989), and so need not necessarily be highly correlated with air temperature. Computations based on mean values of the relevant meteorological variables in the Swiss Alps suggest that the LSET can be expected to decrease linearly with altitude (Kuhn, 1977). In deep lakes, the LSWT tends to coincide roughly with the LSET in summer, and in shallow lakes during most of the rest of the year also (Arai, 1981), so that it is likely that the LSWT will also exhibit an approximately linear decrease with altitude. Studies in tropical lakes suggest that temperatures in lake epilimnia (Vyverman and Sabbe, 1995) and even hypolimnia (Lewis, 1973; Kling et al., 1991) do decrease approximately linearly with altitude; however, the exact form of the altitudinal decrease and its relationship to that of air temperature has not until now been investigated experimentally.

In addition to being affected by altitude, the LSET is also influenced by all other factors that affect the lake heat balance (Edinger et al., 1968; Dingman, 1972). Many of these factors are local or lake-specific, including topographic shading, lake morphometry, wind fetch, wind sheltering, water turbidity and color, river and groundwater inflows, and heat exchange with the sediments. In addition to affecting the LSET, these factors also influence the discrepancy between the LSWT and the LSET and affect the form of the temperature profile, so it cannot be assumed $a$ priori either that lake water temperatures will exhibit a simple linear decrease with increasing altitude or that an individual lake will necessarily be representative of a particular altitude.

Thus, although the factors which regulate LSETs and LSWTs are quite well known, several specific questions of importance for paleoclimate reconstruction remain. (1) Can LSWTs be considered to be identical with the air temperatures prevailing at the altitude of the lake? (2) If not, can we at least assume a linear decrease in LSWT with altitude, and at what rate would such a linear decrease occur? (3) How does the discrepancy between LSWT and air temperature vary with altitude? (4) How important are local effects in creating discrepancies? (5) Should paleolimnologists calibrate their empirical inference models along climate gradients using water temperatures or air temperatures? These questions provided the initial impetus for this study.

\section{Study Region and Measurements}

\section{STUDY REGION}

The region chosen for this study was the southern part of the Canton of Berne, Switzerland (Fig. 1), a rugged, mountainous area where the altitude of the terrain varies between $500 \mathrm{~m}$ a.s.l. and over $4000 \mathrm{~m}$ a.s.1. within about $30 \mathrm{~km}$ from north to south. This area contains many lakes at various altitudes, several of which have been the subject of limnological and paleoecological studies (e.g., von Bühren, 1938; Spengler, 1974; Lotter, 1985; Lotter et al., 1997).

\section{MEASUREMENTS}

Ten lakes were chosen spanning an altitude range of 1746 $\mathrm{m}$, from $613 \mathrm{~m}$ a.s.l. (Burgseewli) to $2339 \mathrm{~m}$ a.s.l. (Hagelseewli) (Fig. 1; Table 1). Throughout the period of the study, an automatic weather station at Hagelseewli recorded air temperature $13 \mathrm{~m}$ above the lake surface at 10 -min intervals. Air temperature data at 10-min intervals were also available from two meteorological stations in the study region: Interlaken (580 $\mathrm{m}$ a.s.1.) and Jungfraujoch (3580 m a.s.1.) (Fig. 1).

Miniature "Minilog" thermistors (Vemco Ltd., Shad Bay, Nova Scotia, Canada) attached to the undersides of $15 \mathrm{~cm} \times 15$ $\mathrm{cm}$ styrofoam blocks were deployed in the lakes during summer 1997 to measure water temperatures $5 \mathrm{~cm}$ below the lake surface at half-hourly intervals. The styrofoam blocks shaded the temperature sensor from direct solar radiation. Where possible, the thermistors were anchored near the lake outflow to ensure a continual flow of epilimnetic water past them, thus minimizing local littoral effects. They were anchored close enough to shore to allow deployment and retrieval without the use of a boat, but in deep enough water $(\sim 1.5 \mathrm{~m})$ and far enough from the lake shore to minimize disturbance and to make unauthorized retrieval unlikely. Despite these precautions, in three cases some disturbance did occur. One thermistor (Schwarzsee) was moved during the investigation, but it was returned close to its original position and no apparent detriment to the measurements resulted. Damage to the float of another thermistor (Seebergsee) resulted in the temperature at the lake bottom (in about $1.5 \mathrm{~m}$ depth) being recorded from 14.9 .97 to 30.9 .97 instead of the temperature 5 $\mathrm{cm}$ below the lake surface. A change in the water level of another lake (Sägistalsee) resulted in a (presumably progressive) reduction of the depth of water below the thermistor from 1.5 $\mathrm{m}$ to $10 \mathrm{~cm}$ during the measurement period, which is likely to have affected the measured water temperatures during September 


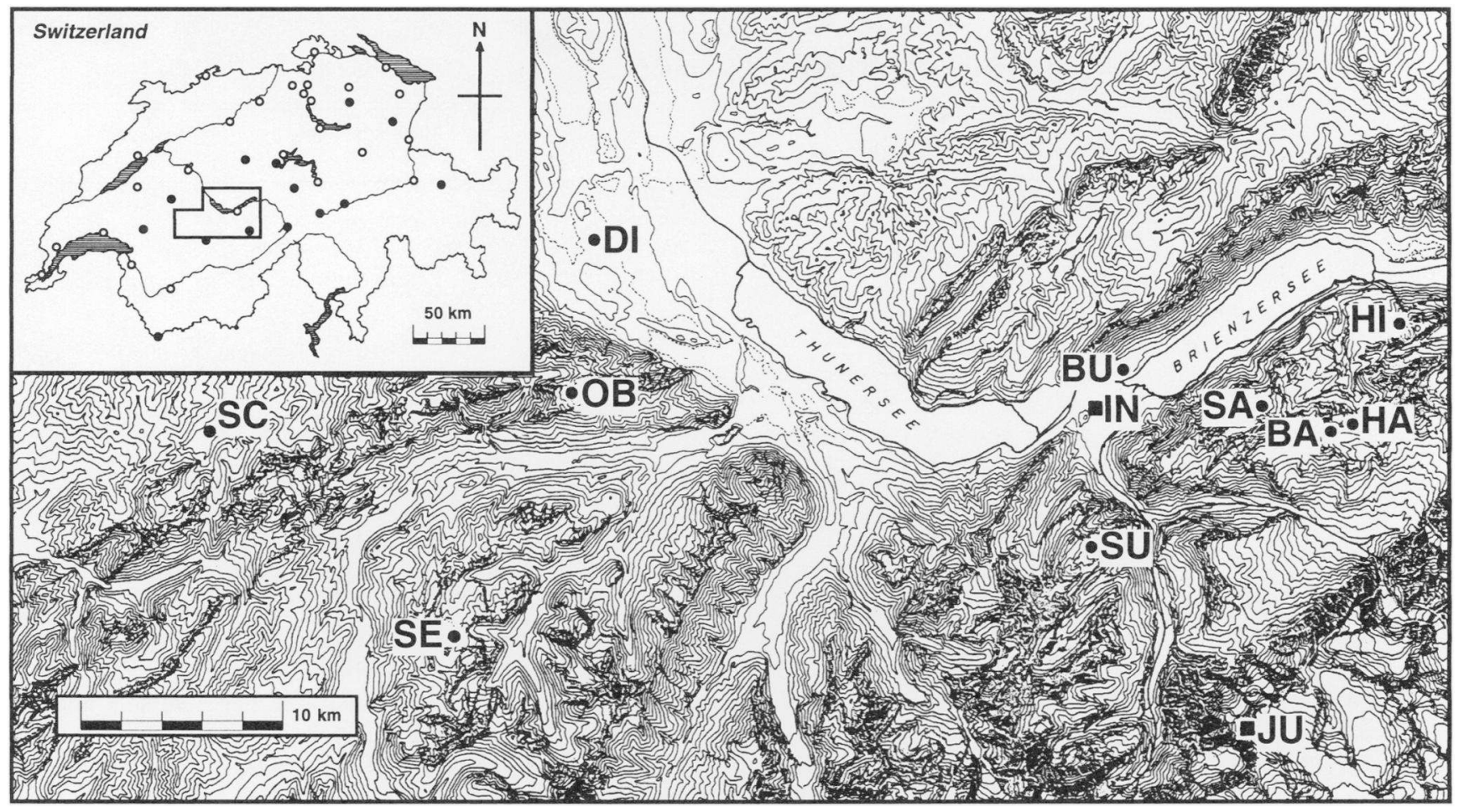

FIGURE 1. Topographic map of the study region in the Bernese Alps, Switzerland, showing the locations of the ten lakes (dots: see Table 1 for names and altitudes) and two meteorological stations (squares: IN = Interlaken, $580 \mathrm{~m}$ a.s.l.; JU = Jungfraujoch, $3580 \mathrm{~m}$ a.s.l.) referred to in the text. The contour intervals are $100 \mathrm{~m}$. The two large lakes, Thunersee and Brienzersee, are situated at 558 and $564 \mathrm{~m}$ a.s.l., respectively, while several of the mountains to the south exceed $4000 \mathrm{~m}$ in altitude. The inset map of Switzerland shows the location of the study area and of the 40 meteorological stations providing data for the computation of surface air temperature lapse rates in the northern Swiss Alps (O: stations $<1000 \mathrm{~m}$ a.s.l.; $\bullet$ stations $\geq 1000 \mathrm{~m}$ a.s.l.).

and October. However, a comparison of the data from the various lakes revealed that any distortion of the results obtained due to these disturbances is likely to be slight, and negligible during the summer months (June-August).

\section{DATA REPRESENTATIVENESS}

In several lakes, measurements were initially made at two different depths to determine whether the temperatures measured at $5 \mathrm{~cm}$ depth could be considered representative of the epilimnion. Typical results are illustrated in Figure 2 for one of these lakes (Hinterburgseeli). During daylight hours, with few exceptions, the temperature difference between $5 \mathrm{~cm}$ and $20 \mathrm{~cm}$ depth did not usually exceed about $1^{\circ} \mathrm{C}$ (the exceptions being on warm, sunny, calm days on which a diurnal stratification could become established). During the night, as a result of convective mixing due to surface cooling, the temperature difference between these two depths rarely exceeded $0.1^{\circ} \mathrm{C}$. This alternation between daytime stratification and nighttime convective mixing is a wellknown phenomenon (Marti and Imboden, 1986). Although the maximum measured temperature difference between $5 \mathrm{~cm}$ and $20 \mathrm{~cm}$ was $1.2^{\circ} \mathrm{C}$, during over $90 \%$ of the time daily mean temperature differences were less than $0.5^{\circ} \mathrm{C}$. The temperature measurements made at $5 \mathrm{~cm}$ can therefore be considered to be fairly representative of the epilimnion.

At Hagelseewli (Fig. 3), one of the remote lakes selected for intensive monitoring within the European Union mountain lake research project "MOLAR," the entire water temperature profile was recorded automatically every $30 \mathrm{~min}$ between 1996 and 1998. These measurements show that Hagelseewli was stratified in summer 1997 and that its deep-water temperature did not exceed $5.5^{\circ} \mathrm{C}$ at any time (Goudsmit et al., 1999). As the lakes in the present study (with the possible exception of Sulsseewli) are at least $10 \mathrm{~m}$ deep (Table 1), and as Hagelseewli is the highest lake with the lowest LSWT (Fig. 4b), all the lakes in this study are likely to have been stratified in summer 1997. Thus, the LSWT, while being representative of the epilimnion and littoral zones, is unlikely to be representative of the hypolimnion of any of these lakes.

\section{Results}

\section{COMPARISON OF AIR AND WATER TEMPERATURES AND TEMPERATURE LAPSE RATES}

A comparison of the daily mean air temperatures measured at Interlaken, Hagelseewli and Jungfraujoch reveals them to have essentially the same temporal structure in summer (Fig. 4a). This is despite the $3000 \mathrm{~m}$ difference in altitude spanned by the stations, and despite differences in local topography (Interlaken being located in a valley, Hagelseewli on a north-facing mountainside and Jungfraujoch on a mountain saddle). The proportion of variance shared pairwise between the three air temperature data series is generally high from June to August (Table 2), but low in September. The low correlation in September is likely to be at least partly due to low-altitude temperature inversions. Linear regressions of daily mean surface air temperature measured at 26 meteorological stations located below $1000 \mathrm{~m}$ a.s.1. on alti- 
TABLE 1

Information pertaining to the 10 study lakes (see also Fig. 1 for locations)

\begin{tabular}{|c|c|c|c|c|}
\hline Lake & Location & $\begin{array}{l}\text { Altitude } \\
\text { (m a.s.1.) }\end{array}$ & $\begin{array}{l}\text { Maximum depth } \\
\text { (m) }\end{array}$ & $\begin{array}{l}\text { Surface area } \\
\left(\mathrm{km}^{2}\right)\end{array}$ \\
\hline 1. Burgseewli (BU) & $46^{\circ} 41^{\prime} 53^{\prime \prime} \mathrm{N} 7^{\circ} 53^{\prime} 05^{\prime \prime} \mathrm{E}$ & 613 & 19 & 0.048 \\
\hline 2. Dittligsee (DI) & $46^{\circ} 45^{\prime} 26^{\prime \prime} \mathrm{N} 7^{\circ} 31^{\prime} 55^{\prime \prime} \mathrm{E}$ & 652 & 17 & 0.070 \\
\hline 3. Schwarzsee (SC) & $46^{\circ} 40^{\prime} 16^{\prime \prime} \mathrm{N} 7^{\circ} 17^{\prime} 17^{\prime \prime} \mathrm{E}$ & 1046 & 10 & 0.425 \\
\hline 4. Hinterburgseeli $(\mathrm{HI})$ & $46^{\circ} 43^{\prime} 12^{\prime \prime} \mathrm{N} 8^{\circ} 04^{\prime} 06^{\prime \prime} \mathrm{E}$ & 1514 & 11 & 0.037 \\
\hline 5. Oberstockensee (OB) & $46^{\circ} 41^{\prime} 13^{\prime \prime} \mathrm{N} 7^{\circ} 31^{\prime} 14^{\prime \prime} \mathrm{E}$ & 1665 & 48 & 0.109 \\
\hline 6. Seebergsee (SE) & $46^{\circ} 34^{\prime} 41^{\prime \prime} \mathrm{N} 7^{\circ} 53^{\prime} 05^{\prime \prime} \mathrm{E}$ & 1831 & 16 & 0.058 \\
\hline 7. Sulsseewli (SU) & $46^{\circ} 37^{\prime} 04^{\prime \prime} \mathrm{N} 7^{\circ} 26^{\prime} 47^{\prime \prime} \mathrm{E}$ & 1917 & - & 0.021 \\
\hline 8. Sägistalsee (SÄ) & $46^{\circ} 40^{\prime} 53^{\prime \prime} \mathrm{N} 7^{\circ} 58^{\prime} 33^{\prime \prime} \mathrm{E}$ & 1935 & 10 & 0.070 \\
\hline 9. Bachsee (BA) & $46^{\circ} 40^{\prime} 09^{\prime \prime} \mathrm{N} 8^{\circ} 01^{\prime} 25^{\prime \prime} \mathrm{E}$ & 2265 & 16 & 0.071 \\
\hline 10. Hagelseewli (HA) & $46^{\circ} 40^{\prime} 29^{\prime \prime} \mathrm{N} 8^{\circ} 02^{\prime} 10^{\prime \prime} \mathrm{E}$ & 2339 & 19 & 0.025 \\
\hline
\end{tabular}

tude yielded positive gradients (indicating inversions) $0 \%$ of the time from June to August 1997 , but $17 \%$ of the time during September 1997. Similar regressions based on data from 14 stations located above $1000 \mathrm{~m}$ a.s.l. revealed no inversions in any of these months (see Fig. 1 for station locations).

The same temporal structure present in the air temperature data series (Fig. 4a) is also present in the water temperature data series (Fig. 4b); this is the case to a certain extent even in September. Again, the proportion of variance shared pairwise between LSWTs is generally high, as is that shared between LSWTs and air temperatures (Table 2). The only obvious exception to this is Hagelseewli, which was totally ice-covered during June and at least partially ice-covered during all of July and part of August, resulting in surface temperatures close to $0^{\circ} \mathrm{C}$ regardless of the prevailing air temperature (Fig. 4b). Thus during summer, essentially the same short-term climatic signal can be assumed to be present in air temperatures and LSWTs over most of the region illustrated in Figure 1, with the exception of lakes that are partially ice-covered during part of the summer. Within the Bernese Oberland region, temporal coherence in the sense of Magnuson et al. (1990) is therefore high with respect to shortterm variations in LWST regardless of altitude.

Despite the common short-term temporal signal, mean LSWTs vary considerably from lake to lake. This variability is primarily altitude-dependent. During the ice-free period, LSWTs in the lowest lake (Burgseewli, $613 \mathrm{~m}$ a.s.l.) and the highest (Hagelseewli, $2339 \mathrm{~m}$ a.s.1.) differed by as much as $18^{\circ} \mathrm{C}$ (Fig. 4b).

Figure 5 illustrates the decrease with altitude of both

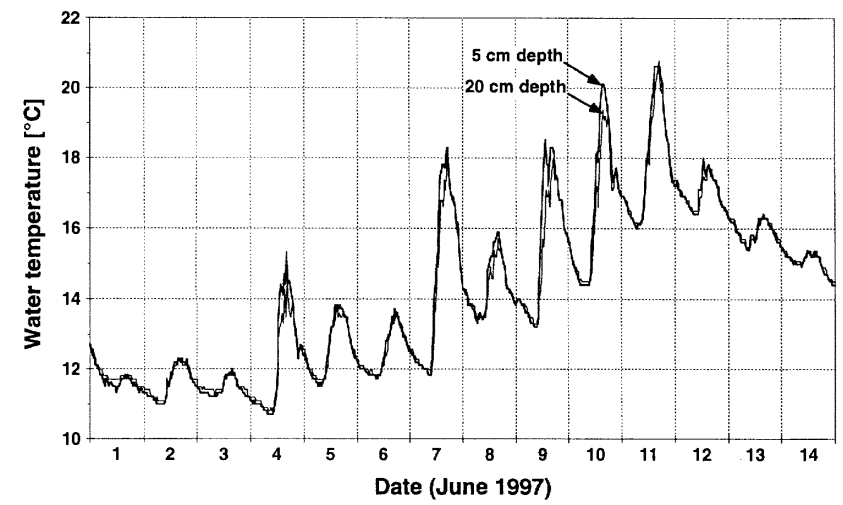

FIGURE 2. Comparison of temperatures measured half-hourly at $5 \mathrm{~cm}$ and $20 \mathrm{~cm}$ depth in Hinterburgseeli during the first two weeks of June 1997. monthly mean air temperature and LSWT in June, July, August, and September 1997, along with the corresponding linear regression lines (because of the exceptionally low water temperatures measured in Hagelseewli, dealt with separately below, data from this lake were excluded from the regression line calculations). During the summer proper (June-August), monthly mean air temperatures were highly correlated with altitude $\left(r^{2}>\right.$ 0.98 in all months), decreasing linearly at rates of 5.7 to $6.1^{\circ} \mathrm{C}$ $\mathrm{km}^{-1}$ (i.e., close to the saturated adiabatic lapse rate). In September, presumably because of the increased incidence of temperature inversions, the correlation was slightly weaker $\left(r^{2}=0.95\right)$ and the overall lapse rate sank to $4.1^{\circ} \mathrm{C} \mathrm{km}^{-1}$ (95\% confidence intervals in all months were narrower than $\left.\pm 0.3^{\circ} \mathrm{C} \mathrm{km}^{-1}\right)$. A more detailed analysis suggests that above about $1000 \mathrm{~m}$ a.s.l. the lapse rate may have remained close to the saturated adiabatic lapse rate in all four months, while decreasing sharply between August and September at lower altitudes due to rapid cooling on the Swiss Plateau (located at about $500 \mathrm{~m}$ a.s.1.).

From Figure 5 it can be seen that the LSWTs are not identical to the air temperatures prevailing at the same altitude. However, they do decrease approximately linearly with increasing altitude, so we can speak of LSWT "lapse rates" ( $\pm 95 \%$ confidence intervals) of $8.1( \pm 2.4){ }^{\circ} \mathrm{C} \mathrm{km}^{-1}$ in June, $6.9( \pm 1.4){ }^{\circ} \mathrm{C}$ $\mathrm{km}^{-1}$ in July, $6.5( \pm 1.2){ }^{\circ} \mathrm{C} \mathrm{km}^{-1}$ in August, and $5.2( \pm 1.6){ }^{\circ} \mathrm{C}$ $\mathrm{km}^{-1}$ in September. However, the linearity of the regressions is less marked than in the case of air temperature, as is obvious from the much broader confidence intervals. In all four months, the computed LSWT "lapse rates" exceed surface air temperature lapse rates; however, the degree of scatter of the LSWT data means that this difference is not statistically significant $(p<$ 0.05 ). The lapse rates of both air temperature and LSWT vary seasonally, decreasing during the course of the summer.

With the exception of Hagelseewli, in all four months at all altitudes LSWTs are substantially higher than the corresponding air temperatures (Fig. 5). Based on the regression lines shown in Figure 5, the calculated mean water-air temperature differences for each of the months June-September are listed in Table 3. Because the LSWT lapse rates exceed the corresponding air temperature lapse rates, the discrepancy between LSWT and air temperature in all four months decreases with increasing altitude. In the mean (June-September), the discrepancy decreases from $4.8^{\circ} \mathrm{C}$ at $500 \mathrm{~m}$ a.s.l. to $3.1^{\circ} \mathrm{C}$ at $2000 \mathrm{~m}$ a.s.l. At all altitudes, the discrepancy increases from July to September (the anomalously high discrepancy in June may be an artifact due to the low number of lakes (4) on which the regression is based). The discrepancy $\left(\Delta \mathrm{T}{ }^{\circ} \mathrm{C}\right)$ between LSWT and air temperature can be estimated for each month as a linear function of altitude $(\mathrm{h} \mathrm{m}$ 


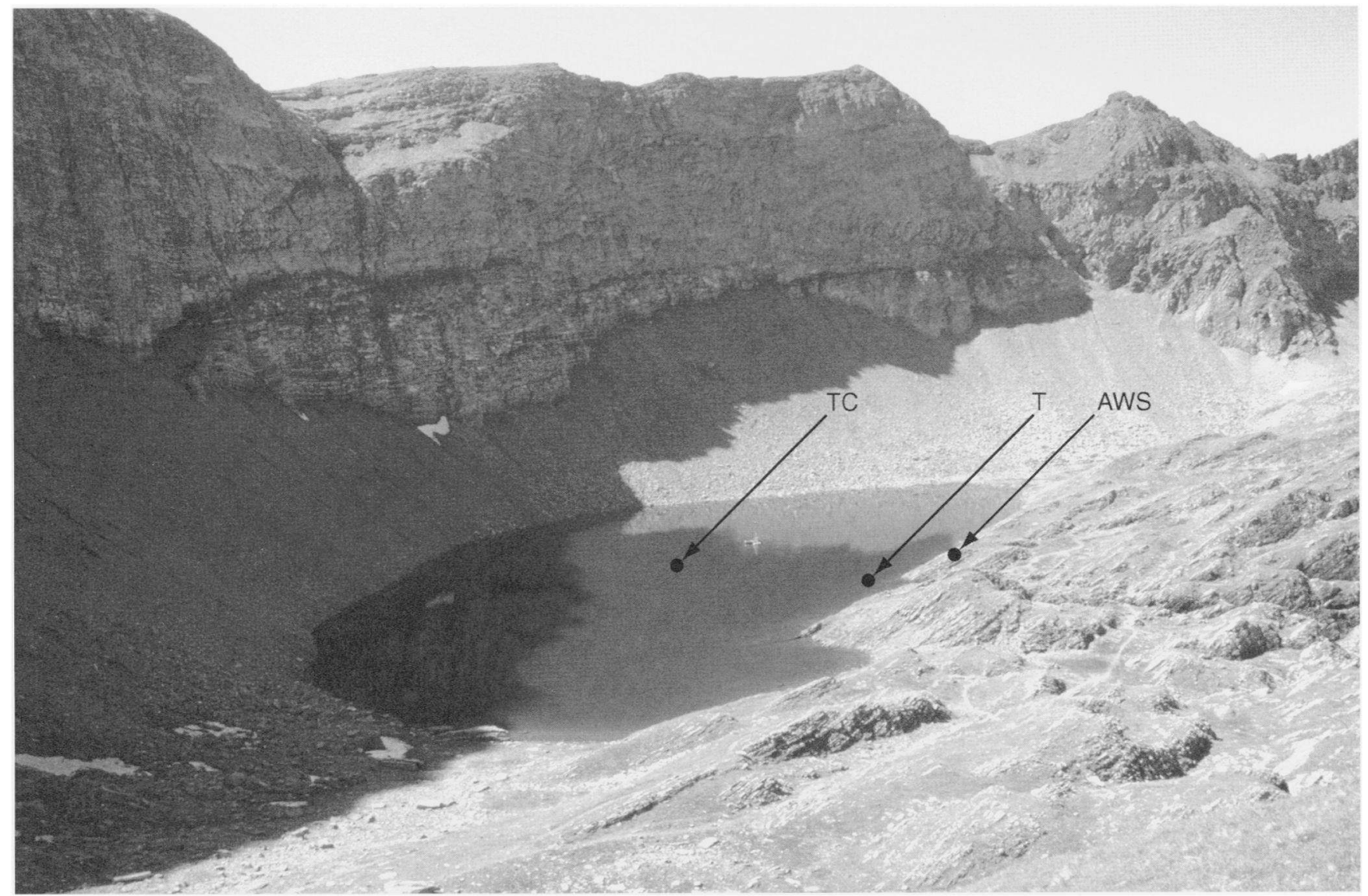

FIGURE 3. Hagelseewli in late summer viewed from the north-east, showing the cliff to the south, its shadow, and the locations of the automatic weather station (AWS), surface thermistor $(T)$ and thermistor chain (TC).

a.s.l.) that can be used to correct LSWT to air temperature (or vice versa):

$$
\begin{array}{ll}
\text { June: } & \Delta \mathrm{T}=6.5-0.0020 \mathrm{~h} \\
\text { July: } & \Delta \mathrm{T}=4.7-0.0009 \mathrm{~h} \\
\text { August: } & \Delta \mathrm{T}=4.8-0.0007 \mathrm{~h} \\
\text { September: } & \Delta \mathrm{T}=5.6-0.0010 \mathrm{~h}
\end{array}
$$

The lapse rates determined here for the LSWT of Swiss Alpine lakes exceed the lapse rate of $4.3^{\circ} \mathrm{C} \mathrm{km}^{-1}$ determined by Vyverman and Sabbe (1995) for the epilimnetic temperature of Papua New Guinea lakes, and also exceed the lapse rates of $3.9^{\circ} \mathrm{C} \mathrm{km}^{-1}$ and $4.0^{\circ} \mathrm{C} \mathrm{km}^{-1}$ determined for the hypolimnetic temperature of tropical lakes by Lewis (1973) and Kling et al. (1991), respectively. They also exceed the July lapse rate of the LSET, $4.8^{\circ} \mathrm{C} \mathrm{km}^{-1}$, calculated for Switzerland by Kuhn (1977) from mean meteorological variables. It is therefore likely that the effects of ice and snow in lake catchment areas, which presumably play a comparatively minor role in tropical lakes and are not accounted for in Kuhn's (1977) LSET calculations, act to increase the LSWT lapse rates in temperate zone mountain areas.

\section{HAGELSEEWLI: THE EFFECTS OF ICE-COVER AND LOCAL TOPOGRAPHIC SHADING}

In Hagelseewli, measured LSWTs were significantly lower than would be expected to prevail at the altitude of that lake based on linear extrapolation of the LSWT regression lines of
Figure 5. This is despite the fact that air temperatures measured at Hagelseewli lie exactly on the air temperature regression line in all months for which data are available (Fig. 5), so the anomalously low water temperatures in Hagelseewli cannot be due to anomalously low air temperatures. In June 1997 the lake was entirely ice-covered, so water temperatures directly at the surface were not measured; however, the temperature at $0.5 \mathrm{~m}$ did not exceed $0.5^{\circ} \mathrm{C}$ (Goudsmit et al., 1999). Thawing, which occurred during July and the first part of August, was spatially very heterogeneous, with open water in the northern part of the lake coexisting with ice cover in the southern part, so that surface water temperatures in the open part of the lake remained close to $0^{\circ} \mathrm{C}$ until about 10 August. Water temperatures were still anomalously low in late August and September, however, even after the ice had completely disappeared from the lake. The main reason for the anomalously low temperatures in Hagelseewli is probably connected with local topography: a high cliff face to the south of the lake rises to over $40^{\circ}$ above the theoretical horizon, causing an extreme reduction in the amount of solar radiation received by the lake (Fig. 3; see also Goudsmit et al., 1999). Solar elevation calculations show that the presence of the cliff reduces the theoretical day length at the center of Hagelseewli from $15.6 \mathrm{~h}$ to $10.3 \mathrm{~h}$ at the summer solstice (21 June) and from $11.9 \mathrm{~h}$ to as little as $3.9 \mathrm{~h}$ at the autumn equinox (21 September). The shift in the radiation balance of the lake due to the obstruction of incident solar radiation by the cliff is therefore in all probability not only the reason for the persistence of anomalously low water temperatures after the lake has completely thawed, but is presumably also the reason for the spatially het- 

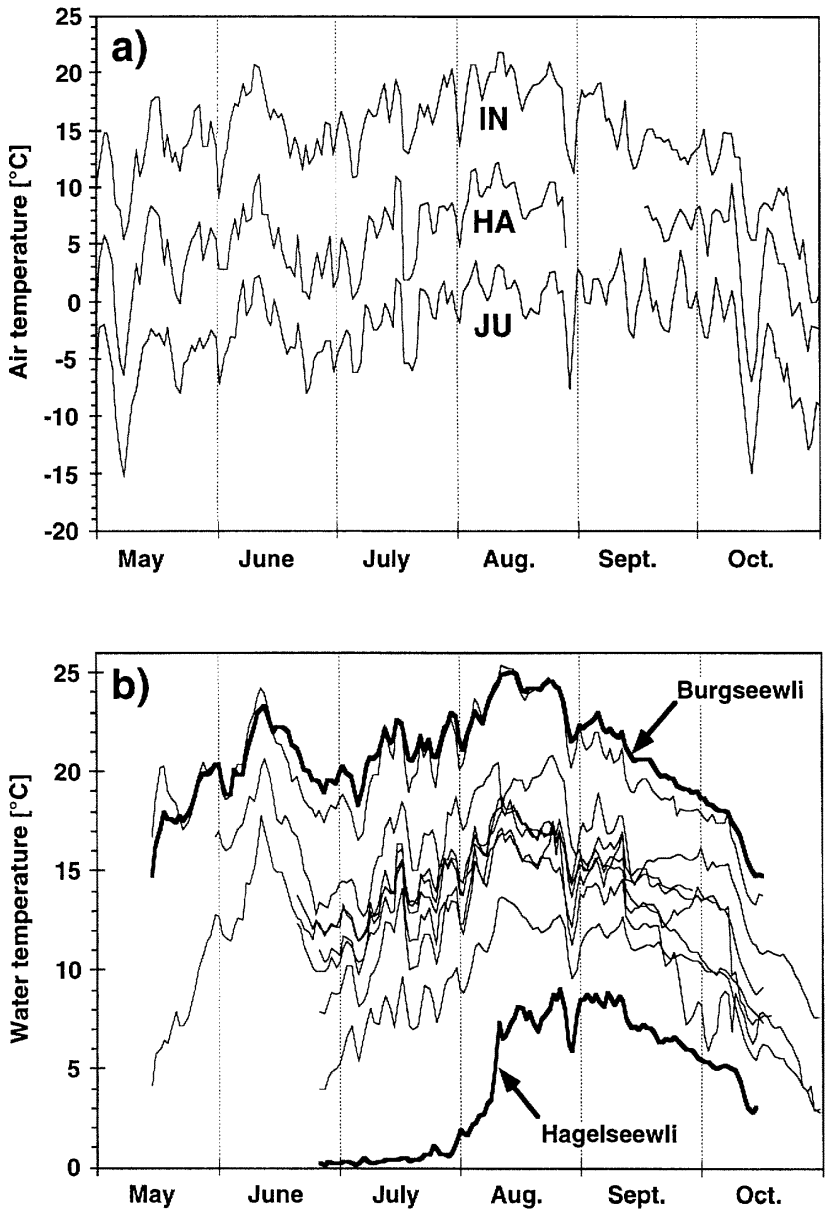

FIGURE 4. a) Daily mean air temperatures measured at the Interlaken (IN, $580 \mathrm{~m}$ a.s.l.), Hagelseewli (HA, $2352 \mathrm{~m}$ a.s.l.) and Jungfraujoch (JU, $3580 \mathrm{~m}$ a.s.l.) meteorological stations, May-October 1997. b) Daily mean water temperatures measured at $5 \mathrm{~cm}$ depth in the 10 lakes (Fig. 1, Table 1) during the same period.

erogeneous thawing of the lake (the southern part of the lake was still ice-covered several weeks after other lakes in the area had entirely thawed).

\section{DAILY LAPSE RATES}

Based on daily mean air temperature data from 40 meteorological stations (see Fig. 1 for locations), the surface air temperature lapse rates prevailing in the northern Swiss Alps were computed for each day of the study period (Fig. 6a). Air temperature lapse rates remain quite constant at about $6^{\circ} \mathrm{C} \mathrm{km}^{-1}$ from May until the end of August. In September they become much more variable, dropping to very low values on days with pronounced inversions, but remaining above $5^{\circ} \mathrm{C} \mathrm{km}^{-1}$ on days on which inversions are weak or absent. Daily LSWT "lapse rates" were determined similarly to the surface air temperature lapse rates, based on data from 3 to 9 lakes (Fig. 6b). Because of ice cover on the highest lakes, the LSWT regressions in May and June are based on data from only 3 to 4 lakes, so that the $95 \%$ confidence intervals are generally wide. However, LSWT "lapse rates" determined on individual days with comparatively narrow confidence intervals confirm the existence of a decreasing trend during May and June (Fig. 6b). This trend, which is not present in the corresponding surface air temper- ature lapse rates, may reflect a decrease in snow and ice in the catchment areas of the higher lakes. In July and August, the LSWT lapse rates are quite constant, and are comparable in value with the corresponding air temperature lapse rates. In September, the day-to-day variability of the LSWT lapse rate is lower than that of the air temperature lapse rate, implying that water temperatures are reacting relatively slowly to meteorological forcing, presumably as a result of the deepening of the surface mixed layer. However, the increase in the width of the $95 \%$ confidence interval of the LSWT "lapse rate" that occurs during September (Fig. 6b) points to a decrease in the degree of linearity of the relationship between LSWT and altitude, which in turn implies the increasing importance of local effects, such as susceptibility to inversions, local topographic shading (due to a decrease in solar elevation) and wind-driven vertical mixing, during this month. Month-by-month calculation of the correlation coefficients between the daily air temperature lapse rates and daily LSWT lapse rates supports the hypothesis that an increase in the frequency of inversions in September may affect LSWT lapse rates. From June to August, when air temperature lapse rates are essentially constant, there is no significant correlation $(r<0.16, p>0.1)$, but in September, when surface air temperature lapse rates begin to vary substantially from day to day, the correlation increases considerably $(r=0.49)$, becoming significant at the $1 \%$ level.

In all months shown in Figure 6, LSWT lapse rates tend to be slightly higher than the corresponding air temperature lapse rates (cf. also Fig. 5). However, the discrepancy is not statistically significant at the $5 \%$ level. In order to decide whether the LSWT and air temperature lapse rates do actually differ, it would be necessary to narrow the confidence intervals of the LSWT lapse rates shown in Figure $6 \mathrm{~b}$ by increasing the number of lakes sampled.

\section{THE DIEL CYCLE IN LAKE SURFACE WATER TEMPERATURE}

LSWTs can exhibit a strong diel cycle (Fig. 2) driven primarily by the diel cycle in solar radiation. The mean diel variation in the LSWT of each of the 10 study lakes is illustrated in Figure 7 for the months of July and August 1997. On average, LSWTs are seen to vary by up to $4^{\circ} \mathrm{C}$ during the diel cycle depending on the lake. It is obvious from Figure 2, however, that this variation can be considerably greater on individual days. The greatest diel range in LSWT found in any lake during the three summer months, $12.1^{\circ} \mathrm{C}$, was observed in Hagelseewli on 10 August 1997. However, this unusually high value is not at all representative of the diel cycle in this lake, but was presumably due to the melting of the last vestiges of ice on the lake, as the daily mean LSWT also underwent a rapid increase on the same day (Fig. 4b). Neglecting this exception, the maximum diel range in LSWT observed during the summer months varied from $4.1^{\circ} \mathrm{C}$ (in Schwarzsee) to as much as $10.0^{\circ} \mathrm{C}$ (in Sulsseewli). Thus in many high-altitude lakes, the maximum range of the diel LSWT cycle is comparable to that of the seasonal cycle, and almost always exceeds day-to-day differences in the daily mean LSWT (cf. Fig. 4b).

No consistent altitudinal trend was observed in the range of the diel cycle (Fig. 7). The mean daily LSWT range in summer (June-August) varied from $1.6^{\circ} \mathrm{C}$ in Bachsee ( $2265 \mathrm{~m}$ a.s.1.) to $3.9^{\circ} \mathrm{C}$ in Sulsseewli (1917 $\mathrm{m}$ a.s.1.).

\section{Discussion: Water Temperatures or Air Temperatures?}

Causally, the thermal habitat of aquatic biota is more closely linked to LSWT than to air temperature; however, air tem- 
TABLE 2

Pairwise coefficients of determination $\left(r^{2}\right)$ between surface water temperatures measured in 10 Swiss Alpine lakes (spanning the altitude range from $613 \mathrm{~m}$ a.s.l. to $2339 \mathrm{~m}$ a.s.l.) and air temperatures measured at 3 neighboring meteorological stations ${ }^{\mathrm{a}}$

\begin{tabular}{|c|c|c|c|c|c|c|c|c|c|c|c|c|c|c|}
\hline & \multirow[b]{2}{*}{ Station } & \multicolumn{10}{|c|}{ Water temperatures } & \multicolumn{3}{|c|}{ Air temperatures } \\
\hline & & $\mathrm{BU}$ & DI & $\mathrm{SC}$ & HI & OB & SB & SU & SÄ & $\mathrm{BA}$ & $\mathrm{HA}$ & $\mathrm{JU}$ & IN & HA \\
\hline \multicolumn{15}{|c|}{ JUNE } \\
\hline \multirow{10}{*}{$\begin{array}{l}\text { Water } \\
\text { temperatures }\end{array}$} & $\mathrm{BU}$ & 1.00 & & & & & & & & & & & & \\
\hline & DI & 0.89 & 1.00 & & & & & & & & & & & \\
\hline & SC & 0.91 & 0.89 & 1.00 & & & & & & & & & & \\
\hline & HI & 0.87 & 0.95 & 0.83 & 1.00 & & & & & & & & & \\
\hline & $\mathrm{OB}$ & - & - & - & - & - & & & & & & & & \\
\hline & SB & - & - & - & - & - & - & & & & & & & \\
\hline & SU & - & - & - & - & - & - & - & & & & & & \\
\hline & $\mathrm{SÄ}$ & - & - & - & - & - & - & - & - & & & & & \\
\hline & $\mathrm{BA}$ & - & - & - & - & - & - & - & - & - & & & & \\
\hline & HA & - & - & - & - & - & - & - & - & - & - & & & \\
\hline \multirow{3}{*}{$\begin{array}{l}\text { Air } \\
\text { temperatures }\end{array}$} & $\mathrm{JU}$ & 0.48 & 0.63 & 0.48 & 0.63 & - & - & - & - & - & - & 1.00 & & \\
\hline & IN & 0.48 & 0.68 & 0.48 & 0.61 & - & - & - & - & - & - & 0.77 & 1.00 & \\
\hline & $\mathrm{HA}$ & 0.43 & 0.62 & 0.43 & 0.63 & - & - & - & - & - & - & 0.76 & 0.76 & 1.00 \\
\hline \multicolumn{15}{|c|}{ JULY } \\
\hline \multirow{10}{*}{$\begin{array}{l}\text { Water } \\
\text { temperatures }\end{array}$} & $\mathrm{BU}$ & 1.00 & & & & & & & & & & & & \\
\hline & DI & 0.91 & 1.00 & & & & & & & & & & & \\
\hline & SC & 0.48 & 0.45 & 1.00 & & & & & & & & & & \\
\hline & $\mathrm{HI}$ & 0.78 & 0.83 & 0.42 & 1.00 & & & & & & & & & \\
\hline & OB & 0.61 & 0.65 & 0.47 & 0.86 & 1.00 & & & & & & & & \\
\hline & SB & 0.87 & 0.84 & 0.49 & 0.78 & 0.56 & 1.00 & & & & & & & \\
\hline & SU & 0.81 & 0.82 & 0.46 & 0.92 & 0.82 & 0.81 & 1.00 & & & & & & \\
\hline & SÄ & 0.76 & 0.73 & 0.67 & 0.73 & 0.70 & 0.85 & 0.78 & 1.00 & & & & & \\
\hline & $\mathrm{BA}$ & 0.48 & 0.46 & 0.28 & 0.44 & 0.35 & 0.57 & 0.53 & 0.60 & 1.00 & & & & \\
\hline & HA & 0.02 & 0.05 & 0.00 & 0.03 & 0.00 & 0.05 & 0.01 & 0.00 & 0.00 & 1.00 & & & \\
\hline \multirow{3}{*}{$\begin{array}{l}\text { Air } \\
\text { temperatures }\end{array}$} & $\mathrm{JU}$ & 0.37 & 0.44 & 0.05 & 0.44 & 0.41 & 0.33 & 0.49 & 0.31 & 0.42 & 0.00 & 1.00 & & \\
\hline & IN & 0.64 & 0.64 & 0.08 & 0.51 & 0.39 & 0.50 & 0.52 & 0.40 & 0.29 & 0.00 & 0.62 & 1.00 & \\
\hline & HA & 0.52 & 0.63 & 0.13 & 0.58 & 0.48 & 0.48 & 0.63 & 0.40 & 0.40 & 0.00 & 0.84 & 0.72 & 1.00 \\
\hline \multicolumn{15}{|c|}{ AUGUST } \\
\hline \multirow{10}{*}{$\begin{array}{l}\text { Water } \\
\text { temperatures }\end{array}$} & $\mathrm{BU}$ & 1.00 & & & & & & & & & & & & \\
\hline & DI & 0.94 & 1.00 & & & & & & & & & & & \\
\hline & SC & 0.58 & 0.60 & 1.00 & & & & & & & & & & \\
\hline & HI & 0.87 & 0.93 & 0.50 & 1.00 & & & & & & & & & \\
\hline & OB & 0.88 & 0.89 & 0.40 & 0.88 & 1.00 & & & & & & & & \\
\hline & SB & 0.94 & 0.92 & 0.48 & 0.88 & 0.94 & 1.00 & & & & & & & \\
\hline & SU & 0.81 & 0.89 & 0.51 & 0.87 & 0.87 & 0.82 & 1.00 & & & & & & \\
\hline & SÄ & 0.93 & 0.96 & 0.56 & 0.94 & 0.90 & 0.94 & 0.84 & 1.00 & & & & & \\
\hline & $\mathrm{BA}$ & 0.91 & 0.89 & 0.46 & 0.84 & 0.95 & 0.94 & 0.79 & 0.89 & 1.00 & & & & \\
\hline & $\mathrm{HA}$ & 0.75 & 0.63 & 0.32 & 0.56 & 0.75 & 0.77 & 0.62 & 0.64 & 0.77 & 1.00 & & & \\
\hline \multirow{3}{*}{$\begin{array}{l}\text { Air } \\
\text { temperatures }\end{array}$} & $\mathrm{JU}$ & 0.14 & 0.25 & 0.09 & 0.25 & 0.23 & 0.17 & 0.42 & 0.20 & 0.13 & 0.13 & 1.00 & & \\
\hline & IN & 0.60 & 0.75 & 0.44 & 0.72 & 0.62 & 0.57 & 0.79 & 0.68 & 0.50 & 0.35 & 0.52 & 1.00 & \\
\hline & HA & 0.56 & 0.65 & 0.61 & 0.59 & 0.50 & 0.49 & 0.65 & 0.57 & 0.47 & 0.33 & 0.32 & 0.66 & 1.00 \\
\hline \multicolumn{15}{|c|}{ SEPTEMBER } \\
\hline Water & $\mathrm{BU}$ & 1.00 & & & & & & & & & & & & \\
\hline temperatures & DI & 0.42 & 1.00 & & & & & & & & & & & \\
\hline & $\mathrm{SC}$ & 0.43 & 0.47 & 1.00 & & & & & & & & & & \\
\hline & $\mathrm{HI}$ & 0.70 & 0.27 & 0.38 & 1.00 & & & & & & & & & \\
\hline & $\mathrm{OB}$ & 0.58 & 0.29 & 0.19 & 0.65 & 1.00 & & & & & & & & \\
\hline & SB & 0.62 & 0.41 & 0.34 & 0.74 & 0.66 & 1.00 & & & & & & & \\
\hline & SU & 0.50 & 0.43 & 0.40 & 0.59 & 0.55 & 0.63 & 1.00 & & & & & & \\
\hline & $\mathrm{SÄ}$ & 0.19 & 0.01 & 0.00 & 0.35 & 0.27 & 0.23 & 0.06 & 1.00 & & & & & \\
\hline & $\mathrm{BA}$ & 0.60 & 0.13 & 0.34 & 0.64 & 0.45 & 0.48 & 0.46 & 0.35 & 1.00 & & & & \\
\hline & $\mathrm{HA}$ & 0.43 & 0.24 & 0.30 & 0.56 & 0.43 & 0.53 & 0.62 & 0.12 & 0.30 & 1.00 & & & \\
\hline Air & $\mathrm{JU}$ & 0.08 & 0.18 & 0.08 & 0.20 & 0.24 & 0.27 & 0.31 & 0.04 & 0.03 & 0.34 & 1.00 & & \\
\hline temperatures & IN & 0.13 & 0.53 & 0.31 & 0.03 & 0.00 & 0.06 & 0.08 & 0.00 & 0.05 & 0.04 & 0.02 & 1.00 & \\
\hline & $\mathrm{HA}$ & - & - & - & - & - & - & - & - & - & - & - & - & - \\
\hline
\end{tabular}

${ }^{a}$ See Figure 1 for lake and meteorological station locations, and Table 1 and Figure 4 for abbreviations used. Seasonal variations were removed by linear detrending within each month before computing $r^{2}$. A dash indicates that $r^{2}$ could not be computed because of insufficient or missing data. Values of $r^{2}$ exceeding 0.17 are significant at the $1 \%$ level (1-tailed $t$-test); nonsignificant values are shown in italics. 


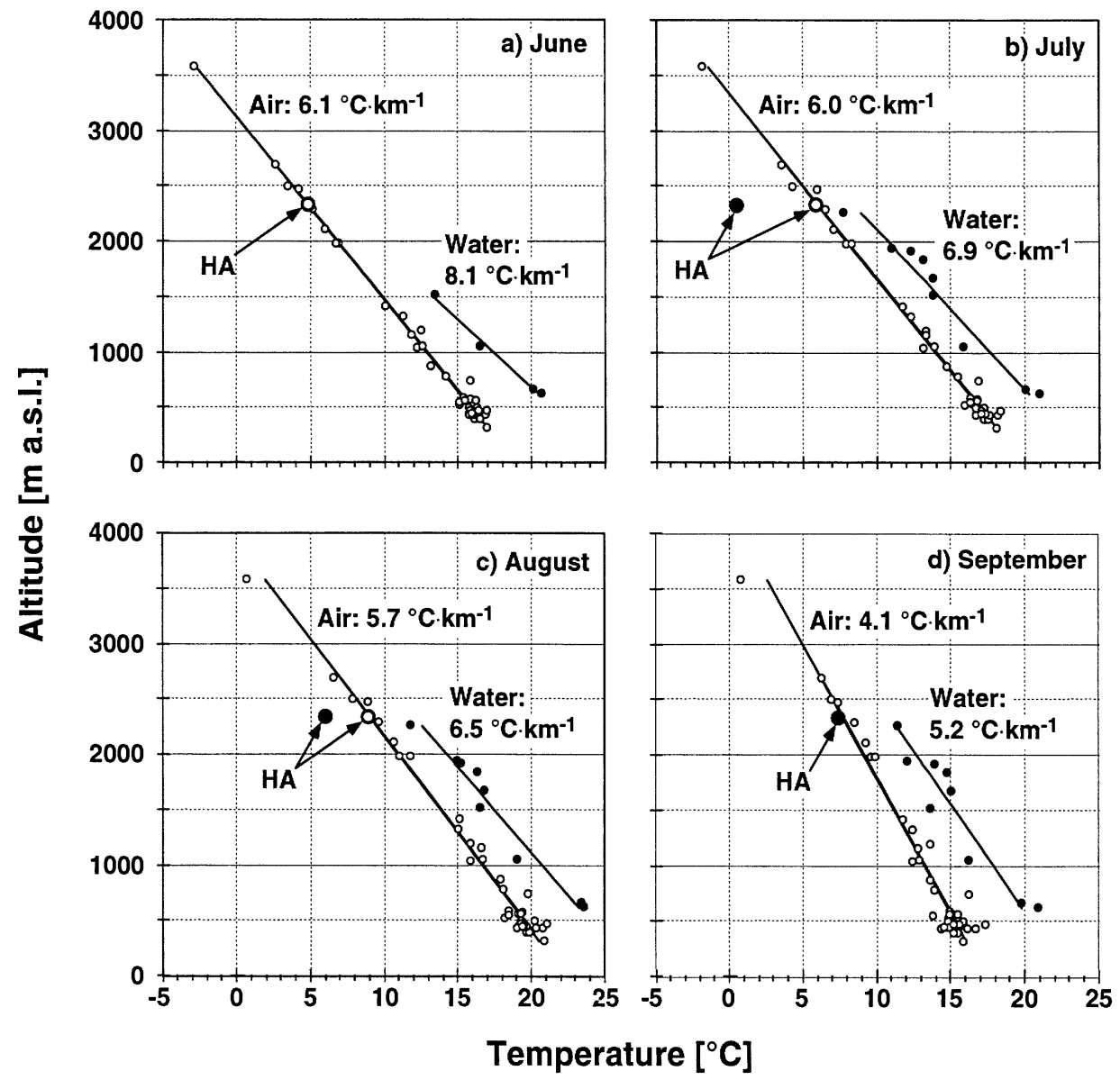

FIGURE 5. The decrease in monthly mean air and lake surface water temperatures with altitude in the northern Swiss Alps, June-September 1997. The monthly mean air temperatures were measured at 40 meteorological stations (for their locations see Fig. 1) The regression lines shown for the air temperatures $(O)$ and water temperatures $(\bullet)$ are significant at the $\mathrm{p}<0.005$ level. The proportion of variance explained for air temperatures was $99.2 \%$ (June), 99.0\% (July), 98.0\% (August) and 95.0\% (September), and for water temperatures $98.6 \%$ (June), 94.1\% (July), 95.4\% (August) and $88.0 \%$ (September). Computed air and water temperature lapse rates were as shown. Air and water temperature data from Hagelseewli (HA, large circles) were not included in the computation of the regression lines shown.

perature is the variable of interest to climatologists. This study shows clearly that paleolimnologically reconstructed water temperatures should not be interpreted as being climatologically equivalent to air temperature (see also Livingstone and Lotter, 1998). Should paleolimnologists instead develop transfer functions that infer air temperatures directly, without first going through the stage of inferring water temperatures (e.g., Lotter et al., 1997)? To address this question, we need to consider first of all what aspect of the thermal environment is likely to be of most importance to the aquatic biota on which the transfer functions are based.

Surface sediment samples for transfer functions are commonly collected in the deepest parts of lake basins, and thus contain remains derived from organisms living at different depths. Since primary producers, such as aquatic macrophytes, diatoms, and chrysophytes, are restricted to the photic zone, the distributions of most species are likely related to epilimnetic temperature. Chironomids and ostracods inhabit both littoral and profundal habitats, and chironomids, like all other aquatic insects, also emerge as adults through the water surface into the air. In the case of chironomids, it is thus unclear which temperature - that of the epilimnion, the hypolimnion, or even the airmight be physiologically most important in governing their dis- tributions, and even less clear which temperature is actually being reconstructed based on their distributions.

To cope with this situation, some paleoecologists have tended to focus their studies on shallow lakes with little or no obvious thermal stratification (e.g., Smith et al., 1998). In instances where shallow lakes are thermally stratified, most subfossils are still likely to have been derived from organisms in the warm epilimnetic and upper littoral regions, and at some later stage to have undergone transport to and redeposition in the deep-water sediments in the central part of the basin (e.g., Walker et al., 1991; Brodersen, 1998; Brodersen and Lindegaard, 1999).

Although ecologists have noted strong correlations between water temperatures and the distributions of aquatic organisms, there is scant evidence that these correlations are based on direct causal relationships. In fact, they are quite likely to be based at least partly on indirect relationships, mediated for example by lake chemistry, rates of weathering, microbial processes, food web interactions or nutrient supply (e.g., Psenner and Schmidt, 1992; Sommaruga-Wögrath et al., 1997). Ultimately, whether these relationships are direct or indirect may be of little consequence for the practical development of quantitative paleoecological temperature inference models, since these are empirical and not deterministic, and therefore require neither a knowledge of relevant processes nor a direct causal link. 
TABLE 3

Monthly mean lake surface water temperatures (LSWT), air temperatures $(A T)$, and their difference $(\Delta T=L S W T-A T)$ for the northern Swiss Alps, interpolated at various altitudes using the regression equations illustrated in Figure 5.

\begin{tabular}{|c|c|c|c|}
\hline & $\begin{array}{c}\text { LSWT } \\
\left({ }^{\circ} \mathrm{C}\right)\end{array}$ & $\begin{array}{l}\text { AT } \\
\left({ }^{\circ} \mathrm{C}\right)\end{array}$ & $\begin{array}{c}\Delta \mathrm{T} \\
\left({ }^{\circ} \mathrm{C}\right)\end{array}$ \\
\hline \multicolumn{4}{|l|}{$500 \mathrm{~m}$ a.s.l. } \\
\hline June & 21.4 & 15.9 & 5.5 \\
\hline July & 21.2 & 17.0 & 4.2 \\
\hline August & 24.0 & 19.5 & 4.4 \\
\hline September & 20.4 & 15.3 & 5.1 \\
\hline \multicolumn{4}{|l|}{$1000 \mathrm{~m}$ a.s.l. } \\
\hline June & 17.4 & 12.9 & 4.5 \\
\hline July & 17.7 & 14.0 & 3.7 \\
\hline August & 20.7 & 16.7 & 4.0 \\
\hline September & 17.9 & 13.3 & 4.6 \\
\hline \multicolumn{4}{|l|}{$1500 \mathrm{~m}$ a.s.l. } \\
\hline June & 13.3 & 9.9 & 3.5 \\
\hline July & 14.3 & 11.0 & 3.3 \\
\hline August & 17.5 & 13.8 & 3.7 \\
\hline September & 15.3 & 11.2 & 4.1 \\
\hline \multicolumn{4}{|l|}{$2000 \mathrm{~m}$ a.s.l. } \\
\hline June & 9.3 & 6.8 & 2.5 \\
\hline July & 10.9 & 8.0 & 2.8 \\
\hline August & 14.3 & 11.0 & 3.3 \\
\hline September & 12.7 & 9.1 & 3.6 \\
\hline
\end{tabular}

For logistical reasons it is usually difficult to obtain good water temperature data for remote lakes. The calibration of paleotemperature inference models is therefore often based on only one summer water temperature measurement (e.g., Walker et al., 1991; Olander et al., 1997), a practice that has attracted some criticism (e.g., Hann et al., 1992). It is obvious from Figure $4 b$ that a single measurement may not yield a representative value for the mean summer LSWT because of weather-dependent dayto-day variations in LSWT. However, if it is possible to sample all the lakes involved in a calibration study on the same day, this source of relative error can be eliminated to a large extent, although the absolute error (the discrepancy between the measured LSWT and the mean summer LSWT) remains. Spatial heterogeneity in the weather conditions within the study area on the sampling day will also introduce an error into the calibration, but this error will be small if the daily mean LSWTs are wellcorrelated along the climate gradient (as they are for instance in this study). A more difficult problem is presented by the diel cycle in LSWT. In the lakes studied here, the LSWT daily minimum generally occurs between $7 \mathrm{~h}$ and $10 \mathrm{~h}$, and the daily maximum between $14 \mathrm{~h}$ and $17 \mathrm{~h}$ (Fig. 7). Thus if single LSWT measurements are conducted in each of several lakes during the course of the same day, those measurements made early in the day will tend to underestimate the daily mean, while those made later in the day will tend to overestimate it. This is most likely to bias the paleolimnological temperature inference models if the order in which the lakes are sampled is the same as their order along the climate gradient. If the lakes are sampled systematically from low to high altitude (or latitude) during the course of a day, the climate gradient will be underestimated; if sampling is conducted in the reverse direction, it will be overestimated. It is not possible to correct this error if the range of the diel cycle

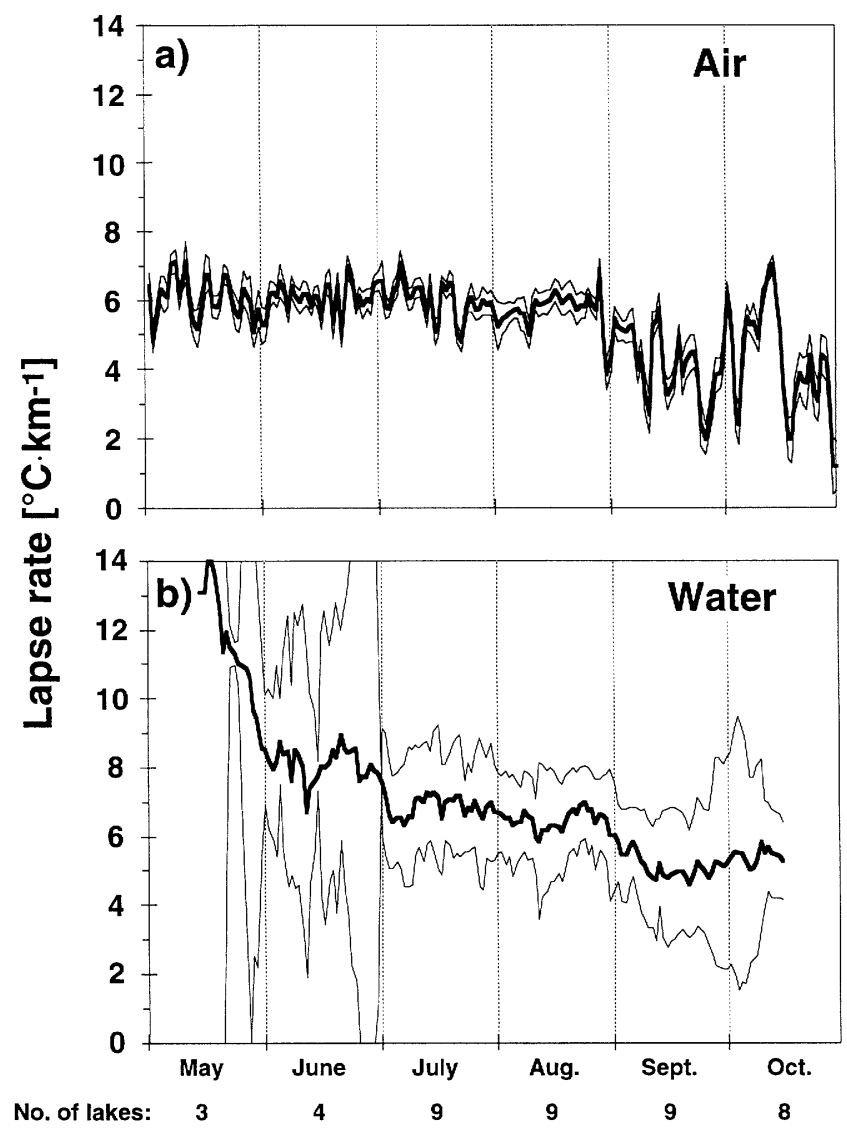

FIGURE 6. Surface air temperature and lake surface water temperature (LSWT) lapse rates prevailing in the northern Swiss Alps, May-October 1997, based on linear regressions of daily mean temperatures on altitude. a) Daily surface air temperature lapse rates, based on daily mean air temperature data from 40 meteorological stations. b) Daily LSWT "lapse rates", based on daily mean LSWT data from 3 to 9 lakes. See Figure 1 for locations. $95 \%$ confidence intervals are denoted by dashed lines.

in LSWT is unknown; however, sampling in overcast conditions (warm nights, cold days) rather than clear, sunny conditions (cold nights, warm days) will reduce the magnitude of the diel cycle and the associated error.

In contrast to lake water temperature data, long and reliable air temperature time series are often readily available from regional meteorological stations, allowing air temperatures at lakes to be estimated quite accurately and with relative ease by applying appropriate lapse rates. Relevant information is often available in geographic information system climate atlases. There are therefore several advantages to employing air temperatures directly in paleolimnological temperature inference models. Chief among these is their generally better availability, coupled with the fact that air temperature, not LSWT, is the variable that paleoclimatologists most wish to reconstruct, and is also the relevant variable for GCM hindcasting. The main disadvantage to the use of air temperatures is the lack of a well-defined causal link between air temperature and the aquatic habitat. However, because temperature inference models are empirical, the lack of a direct deterministic connection does not necessarily preclude the use of any environmental variable, regardless of the degree of causality involved. There would therefore seem to be no compelling reason to use water temperature rather than air temperature in the development of paleolimnological transfer functions, 


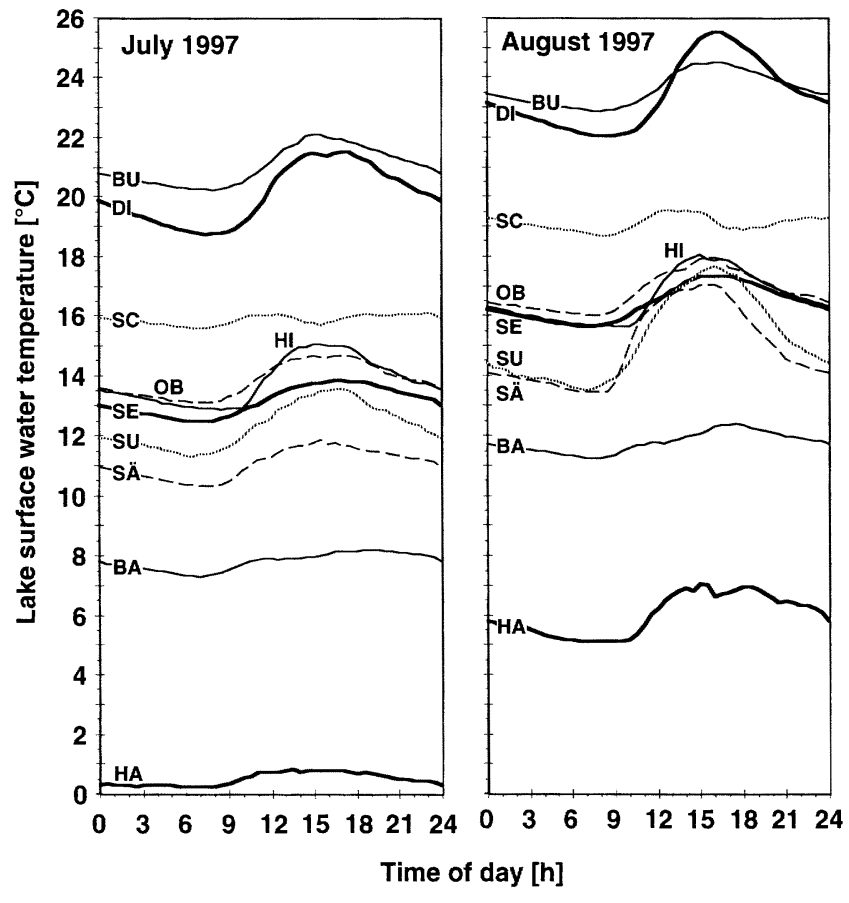

FIGURE 7. Mean diel variations in the surface water temperatures of each of the 10 study lakes in July and August 1997. See Table 1 for lake names.

and it would certainly be more convenient for paleoclimatologists if paleoenvironmental data could be employed to estimate air temperatures directly without going through the intermediate stage of estimating lake water temperatures.

Our results suggest that the linear relationship between air and water temperature lapse rates may break down above about $2000 \mathrm{~m}$ a.s.l., because lakes at these altitudes (regardless of local factors such as topographic shading or meltwater inflow) are only ice-free for a short period during summer. Such high-altitude lakes are thus decoupled from atmospheric forcing for most of the year, so that the duration of the ice-free period, rather than the magnitude of summer water or air temperatures, may be the primary climatic forcing mechanism for biological activity (see e.g., Smol, 1988).

\section{Summary and Conclusions}

\section{SUMMARY OF RESULTS}

During the ice-free period in summer, LSWTs and air temperatures in a mountain region have been shown to be temporally coherent, exhibiting a similar short-term structure over a range of about $60 \mathrm{~km}$ horizontally and $1700 \mathrm{~m}$ vertically (Fig. 4). LSWTs tend to be about 3 to $5^{\circ} \mathrm{C}$ higher than the air temperature prevailing at the altitude of the lake (Table 3; Fig. 5).

The decrease in summer LSWT with increasing altitude is approximately linear (Fig. 5), allowing an LSWT "lapse rate" to be defined that is comparable to, although slightly greater than, the prevailing summer surface air temperature lapse rate (Fig. 6).

Large diel variations in LSWT (Figs. 2, 7) imply that single measurements are unlikely to be representative of the mean.

Topographic shading results in a depression of LSWT with respect to air temperature and with respect to the LSWT of lakes not subject to such shading because of the blocking of incident solar radiation and because of the extension of the period of partial ice cover due to spatially heterogeneous thawing. Local factors such as topographic shading, partial ice cover and meltwater inflows will affect lake water temperatures more than they affect air temperatures, resulting in potentially severe distortion of any simple empirical relationship between the two.

In early autumn, the effect of air temperature inversions on the one hand and of vertical mixing driven by surface cooling and wind on the other can complicate the empirical relationship between LSWT and air temperature. This suggests that studies that rely on the existence of a simple monotonic relationship between LSWT and air temperature to convert reconstructed LSWTs to air temperatures should be confined to the summer proper, i.e., June-August. At high altitudes, this may need to be further restricted to the months of July and August because of the presence of ice cover in June.

\section{IMPLICATIONS FOR PALEOLIMNOLOGICAL STUDIES}

In paleolimnological studies based on an altitudinal climate gradient, the assumption of a linear decrease in LSWT with increasing altitude is generally defensible. However, reconstructed LSWTs are likely to be several degrees warmer than corresponding air temperatures.

Lakes should be selected to minimize local effects distorting the relationship between LSWT and air temperature in summer. They should ideally have a southern exposure (in the Northern Hemisphere) and a long ice-free season.

Calibration studies should not be based on single measurements of water temperature because of the risk of introducing a bias into the estimated mean summer LSWT. With the availability of inexpensive thermistors of sufficiently high resolution for biological work there is now little need to rely on single manual measurements.

Consideration should be given to calibrating paleolimnological temperature inference models in terms of air temperature rather than water temperature (e.g., Lotter et al., 1997). This has the advantage of allowing air temperature (the climate variable of interest) to be reconstructed directly instead of first inferring water temperature and then making possibly unfounded tacit assumptions about the relationship between water temperature and air temperature.

The importance of ice cover to the relationship between air temperature and the habitat of aquatic biota should not be forgotten. The timing of freeze-up and the timing of break-up, both critical determinants of light, temperature, mixing and nutrient regimes in high-altitude and high-latitude lakes, are highly correlated with air temperature averaged over several weeks previous to the mean freeze-up or break-up date (e.g., Palecki and Barry, 1986; Livingstone, 1997). The primary climate effect on the aquatic biota of such lakes may therefore be mediated by the relative durations of the periods of total ice cover, partial ice cover and open water, and be related not to the temperatures prevailing during the open-water period, but rather to those prevailing before freeze-up and during the thawing process.

This study represents an initial attempt to clarify the empirical relationship existing between air and lake water temperatures along a climate gradient, and to explore potential implications for paleolimnological temperature reconstruction. Future studies might involve a similar investigation along a latitudinal climate gradient, a more detailed investigation of local effects, and research into the possibility of changes in the form of the relationship between air and lake water temperatures having occurred with time because of changes in meteorological forcing. 


\section{Acknowledgments}

Air temperature data from Interlaken, Jungfraujoch, and 38 other meteorological stations were supplied by the Swiss Meteorological Institute. Figure 1 is based on contouring information supplied by the Swiss Federal Office of Topography. The assistance of $\mathrm{O}$. Heiri and G. Lemcke in the field is gratefully acknowledged. Funding was provided by the Swiss Federal Office of Education and Science (Grant No. 95.0518-1 and 97.0344) within the framework of the European Union Environment and Climate projects MOLAR ('Measuring and Modelling the Dynamic Response of Remote Mountain Lake Ecosystems to Environmental Change: a Program of Mountain Lake Research'; Contract No. ENV4-CT95-007) and REFLECT ('Response of European Freshwater Lakes to Environmental and Climatic Change'; Contract No. ENV4-CT97-0453), and by the Swiss National Science Foundation within the framework of Priority Program Environment project 5001-044600. The participation of IRW was assisted by the Hans Sigrist Stiftung and by a research grant from the Natural Sciences and Engineering Research Council of Canada.

\section{References Cited}

Arai, T., 1981: Climatic and geomorphological influences on lake temperature. Verhandlungen der internationalen Vereinigung der Limnologie, 21: 130-134.

Barry, R. G., 1992: Mountain Weather and Climate. 2nd ed. London and New York: Routledge. 402 pp.

Beniston, M., Diaz, H. F., and Bradley, R. S., 1997: Climatic change at high elevation sites: an overview. Climatic Change, 36: 233-251.

Brodersen, K. P., 1998: Macroinvertebrate communities in Danish lakes: classification and trophic reconstruction. Ph.D. thesis, University of Copenhagen. $143 \mathrm{pp}$.

Brodersen, K. P. and Lindegaard, C., 1999: Classification, assessment and trophic reconstruction of Danish lakes using chironomids. Freshwater Biology (42: 143-157).

Dingman, S. L., 1972: Equilibrium temperatures of water surfaces as related to air temperature and solar radiation. Water Resources Research, 8: 42-49.

Edinger, J. E., Duttweiler, D. W., and Geyer, J. C., 1968: The response of water temperatures to meteorological conditions. Water Resources Research, 4: 1137-1143.

Goudsmit, G.-H., Lemcke, G., Livingstone, D. M., Lotter, A. F., Müller, B., and Sturm, M., 1999: Hagelseewli: a fascinating high mountain lake - suitable for palaeoclimate studies? Verhandlungen der internationalen Vereinigung der Limnologie, 27 (in press).

Hann, B. J., Warner, B. G., and Warwick, W. F., 1992. Aquatic invertebrates and climate change: a comment on Walker et al. (1991). Canadian Journal of Fisheries and Aquatic Sciences, 49: 1274-1276.

Kattenberg, A., Giorgi, F, Grassl, H., Mehl, G. A., Mitchell, J. F. B., Stouffer, R. J., Tokioka, T., Weaver, A. J., and Wigley, T. M. L., 1996: Climate models-projections of future climate. In Houghton, J. J., Meiro Filho, L. G., Callender, B. A., Harris, N., Kattenberg A., and Maskell, K. (eds.), Climate Change 1995-the science of climate change. Contribution of Working Group I to the Second Assessment Report of the Intergovernmental Panel on Climate Change. Cambridge: Cambridge University Press, 285-357.

Kling, G. W., Evans, W. C., and Tuttle, M. L., 1991: A comparative view of Lakes Nyos and Monoun, Cameroon, West Africa. Verhandlungen der internationalen Vereinigung der Limnologie, 24: 1102-1105.

Kuhn, W., 1977: Berechnung der Temperatur und Verdunstung alpiner Seen auf klimatologisch-thermodynamischer Grundlage. Arbeitsbericht der Schweizerischen Meteorologischen Anstalt, No. 70, Zurich. 46 pp.
Lewis, W. M., Jr., 1973: The thermal regime of Lake Lanao (Philippines) and its theoretical implications for tropical lakes. Limnology and Oceanography, 18: 200-217.

Livingstone, D. M., 1997: Break-up dates of Alpine lakes as proxy data for local and regional mean surface air temperatures. Climate Change, 37: 407-439.

Livingstone, D. M. and Imboden, D. M., 1989: Annual heat balance and equilibrium temperature of Lake Aegeri, Switzerland. Aquatic Sciences, 51: 351-369.

Livingstone, D. M. and Lotter, A. F., 1998: The relationship between air and water temperatures in lakes of the Swiss Plateau: a case study with palaeolimnological implications. Journal of Paleolimnology, 19: 181-198.

Lotter, A. F, 1985: Amsoldingersee-Late-Glacial and Holocene environments of a lake at the southern edge of the Swiss Plateau. Dissertationes Botanica, 87: 185-208.

Lotter, A. F., Birks, H. J. B., Hofmann, W., and Marchetto, A., 1997: Modern diatom, cladocera, chironomid, and chrysophyte cyst assemblages as quantitative indicators for the reconstruction of past environmental conditions in the Alps. I. Climate. Journal of Paleolimnology, 18: 395-420

Magnuson, J. J., Benson, B. J., and Kratz, T. K., 1990: Temporal coherence in the limnology of a suite of lakes in Wisconsin, U.S.A. Freshwater Biology, 23: 145-159.

Marti, D. and Imboden, D. M., 1986: Thermische Energieflüsse an der Wasseroberfläche: Beispiel Sempachersee. Schweizerische Zeitschrift für Hydrologie, 48: 196-229.

Olander, H., Korhola, A., and Blom, T., 1997: Surface sediment Chironomidae (Insecta: Diptera) distributions along an ecotonal transect in subarctic Fennoscandia: developing a tool for palaeotemperature reconstructions. Journal of Paleolimnology, 18: 45-59.

Palecki, M. A. and Barry, R. G., 1986: Freeze-up and break-up of lakes as an index of temperature changes during the transition seasons: a case study for Finland. Journal of Climate and Applied Meteorology, 25: 893-902.

Pienitz, R., Smol, J. P., and Birks, H. J. B., 1995: Assessment of freshwater diatoms as quantitative indicators of past climatic change in the Yukon and Northwest Territories, Canada. Journal of Paleolimnology, 13: 21-49.

Psenner, R., and Schmidt, R., 1992: Climate-driven pH control of remote alpine lakes and effects of acid deposition. Nature, 356: 781-783.

Smith, M. J., Pellatt, M. G., Walker, I. R., and Mathewes, R. W., 1998: Postglacial changes in chironomid communities and inferred climate near treeline at Mount Stoyoma, Cascade Mountains, southwestern British Columbia, Canada. Journal of $\mathrm{Pa}$ leolimnology, 20: 277-293.

Smol, J. P., 1988: Palaeoclimate proxy from freshwater arctic diatoms. Verhandlungen der internationalen Vereinigung der Limnologie, 23, 837-844.

Smol, J. P., Walker, I. R., and Leavitt, P. R., 1991: Paleolimnology and hindcasting climatic trends. Verhandlungen der internationalen Vereinigung der Limnologie, 24: 1240-1246.

Sommaruga-Wögrath, S., Koinig, K. A., Schmidt, R., Sommaruga, R., Tessadri, R., and Psenner, R., 1997: Temperature effects on the acidity of remote alpine lakes. Nature, 387: 6467.

Spengler, D., 1974: Limnologische, hydrologische und morphologische Untersuchungen im Faulhorngebiet (Berner Oberland). Ph.D. thesis, University of Berne. 155 pp.

Tabony, R. C., 1985: The variation of surface temperature with altitude. Meteorological Magazine, 114: 37-48.

von Bühren, G., 1938: Der Amsoldingersee. Mitteilungen der Naturforschenden Gesellschaft in Bern, 1937: 50-132.

Vyverman, W. and Sabbe, K., 1995: Diatom-temperature transfer functions based on the altitudinal zonation of diatom assemblages in Papua New Guinea: a possible tool in the reconstruction of regional palaeoclimatic changes. Journal of Paleolimnology, 13: 65-77. 
Walker, I. R., Smol, J. P., Engstrom, D. R., and Birks, H. J. B., 1991: An assessment of Chironomidae as quantitative indicators of past climatic change. Canadian Journal of Fisheries and Aquatic Sciences, 48: 975-987.

Walker, I. R., Levesque, A. J., Cwynar, L. C., and Lotter, A. F., 1997: An expanded surface-water palaeotemperature inference model for use with fossil midges from eastern Canada. Journal of Paleolimnology, 18: 165-178.

Weckström, J., Korhola, A., and Blom, T., 1997: The relation- ship between diatoms and water temperature in thirty subarctic Fennoscandian lakes. Arctic and Alpine Research, 29: 75-92.

Wunsam, S., Schmidt, R., and Klee, R., 1995: Cyclotella-taxa (Bacillariophyceae) in lakes of the Alpine region and their relationship to environmental variables. Aquatic Sciences, 57: 360-386.

Ms submitted October 1998 